\title{
PEMBELAJARAN PENDIDIKAN AGAMA ISLAM DALAM PEMBINAAN AQIDAH AKHLAK
}

\section{Oleh Nur'aini \\ STAl Ibnu Sina Batam \\ Email: nur_aini748@yahoo.com}

Abstract: Pendidikan dalam kehidupan manusia, memupunyai peranan yang sangat penting yang dapat membantu kepribadian seseorang melalui pembelajaran, Islam menempatkan pendidikan pada kedudukan yang tinggi, karena pendidikan agama Islam pada dasarnya membina akidah akhlak sebagai suatu keyakinan yang tumbuh dan berakar dalam hati, bukan pada lisan atau pikiran sesorang, akan tetapi sebagai pondasi bagi seseorang untuk berpikir dan bertingkah laku, dengan tujuan mengantarkan dan membentuk manusia seutuhnya yang beriman dan bertakwa serta berakhlah muliah, sehingga menjadi manusia cerdas, terampai, berbudi luhur, bertangung jawab terhadap diri sendiri dan masyarakat, guna tercapai kebahagiaan dunia dan akhirat Kata Kunci: Pemuda hijrah, Kesalehan, Gaya hidup 


\section{PEMBELAJARAN PENDIDIKAN AGAMA ISLAM DALAM PEMBINAAN AQIDAH AKHLAK}

\section{Oleh Nur'aini \\ STAI Ibnu Sina Batam \\ Email: nur_aini748@yahoo.com}

\section{Pendahuluan}

Pendidikan sebagai bagian integral dari kehidupan masyarakat di era global harus memberikan dan menfasilitasi bagi perkembangan keterampilan intelektual, sosial, dan personal. Pendidikan dalam arti luas segala pengalaman belajar yang dilalui peserta didik dengan segala lingkungan dan sepanjang hayat. Pendidikan harus menumbuhkan berbagai potensi peserta didik, keterampilan intelektual, sosial dan personal tidak hanya dengan landasan rasio dan logika saja tetapi juga inspirasi, keaktivitas, moral, emosi dan spritual. ${ }^{1}$

Pendidikan agama Islam memiliki peranan yang sengan penting dalam membentukan peserta didik yang memiliki aqidah akhlak yang baik. Dengan melalui pendidikan agama Islam diharapkan peserta didik menjadi orang yang beriman dan berakhlak mulia. Dengan pendidikan agama Islam merupakan salah satu upaya pengembagan sumber daya manusia ke arah yang lebih relegius. Karena pendidikan manusia dapat berkembang dengan baik, sehingga peningkatan kualitas pembelajaran terus-menerus dilakukan untuk mendapatkan hasil yang maksimal. ${ }^{2}$

${ }^{1}$ Agung Suprijono, Comeraive Learning tweri dan Alikas aikem (Yogjakarta: ustaka Pelajar, 2011),hal. VI

${ }^{2}$ Sulistyorini, Manajemen Pendidikan Islam, aplikasi, Strategi, dan Aplikasih (Yogyakarta : Teras 209), hal. 221

2 Jurnal Madania: Volume 9 : 1, 2019 (e-ISSN 2620-8210| p-ISSN 2088-3226) 
Ajaran Islam yang universal mengantar manusia menuju kehidupan bahagia dunia dan akhiat. Ajaran agama Islam sebagaimana yang tecatum dalam al-Qur'an secara umum aqidah dan akhlak, masing-masing satu samalain saling berkaitan dan merupakan bagian yang integral. Aqidah merupakan ajaran dasar dan ruh bagi setiap muslim yang menginginkan kehidupan baik, karena terkai dengan masalah ketuhanan yang didalamnya dibahas keimanan dan ketaqwaan. Kemudian cara untuk memperkuat keimanan dan ketaqwaan. Ahklak merupakan pelengkap kehiupan manusia agar bermartabat tidak hanya di hadapan Allah SWT. tetapi juga dihadapan sesamanya. Ahklah juga sebagai penghias hidup manusia dan merupakan buah dari pengalaman kedua ajaran yaitu aqidah dan akhlak. ${ }^{3}$

Pendidikan agama Islam pada dasarnya bertujuan mengantarkan dan membentuk manusia seutuhnya yang beriman dan bertakwa serta membentuk manusia cerdas, terampai, berbudi luhur, bertangung jawab terhadap diri sendiri dan masyarakat guna tercapai kebahagiaan dunia dan akhirat. ${ }^{4}$ Tujuan dari pendidikan aqidah akhlak yaitu membentuk diri dan relegius dan berakar pada hati nurani, sikap yang religious akan memisahkan anak dari kebebasan buruk dan sifat negatif, tetapi sulit untuk mencapai tujuan terbut manakala dalam proses pembelajaran kurang memperhatikan metode pembengajaran.

Menurut Wina Sanjaya, metode adalah cara yang digunakan untuk mengimplementasikan rencana yang sudah disusun dalam kegiatan nyata agar tujuan tercapai seca optimal, metode dalam rangkaian sistem pembelajaran memegang peran yang sangat penting, karena keberhasilan peoses belajar mengajar targantung paca caran mengunakan metode pembelajaran. ${ }^{5}$ Pemakaian metode yang tepat sangat membantu untuk mencapai tujuan pendidikan, metode harus dipilih yang sesuai dengan materi yang

${ }^{3}$ Enang Hidayat, Pendidikan Agama IslamIntegrasi Nilai-Nilai Aqidah Alkhkan (Bandung: PT. Ramaja Rodaksrys 2018), hal. V.

${ }^{4}$ Akmal Wahi, Kompetensi Guru Pendidikan agama Islam (Jakarta: ajawali Press, 2014), hal. 21.

${ }^{5}$ Wina Sanjaya, Stategi embelajaran Berorintasi Standar Pendidikan (Jakarta: Kencana renada Media Group, 2014), hal. 147.

Nur'aini: Pembelajaran Pendidikan Agama ...3 
akan disampaikan. Karena tidak ada suatu metode yang paling baik untuk semua materi, oleh karena itu pemakaian metode harus disesuaikan dengan materi masing-masing. Karena Metode yang digunakan sangat berpengaruh dalam meningkatkan motivasi dan kenyamanan belajar.

Pembelajaran pada dasarnya suatu peroses penambahan informasi dan kemampuan baru. Pembelajaran yang baik adalah selalu memposisikan diri sebagai subjek yang mendominasi peroses pembelajaran dan tidak menjadi siswa hanya sebagai objek, tetapi guru mampu menciptakan suasana yang kondusif, edukatif dan inofatif dalam belajar serta mampu membiming siswa sehingga terjadi perubahan positif tingkah laku kognitif, efektif dan psikomotor pada siswa. ${ }^{6}$

Berdasarkan latar belakang, maka rumusan masalah yang akan penulis hadirkan adalah sebagai berikut:

a. Bagamana pelaksanaan pembelajaran pendidikan agama Islam dalam membina aqidah akhlah ?

b. Metode pembelajaran apa yang tepat digunakan dalam pembinaan aqidah akhlak ?

\section{Tujuan Penelitian}

a. Untuk mengetahui pelaksanaan pembelajaran pendidikan agama Islam dalam membina aqidah akhlah

b. Untuk mengetahui Metode Pembelajaran yang tepat digunakan dalam pembinaan aqidah akhlak

\section{Metode Penelitian}

1. Pendekatan Penelitian

Penelitian ini, penulis menggunakan model pendekatan content analisis (kajianisi), penelitian ini bersifat pembahasan yang mendalam terhadap isi suatu informasi tertulis atau tercetak dalam media massa. Analisis ini biasanya digunakan pada penelitian kualitatif. content analysis (kajian isi) secara umum diartikan sebagai metode yang meliputi semua analisis mengenai isi teks, tetapi disisi lain analisis isi juga digunakan untuk mendeskripsikan pendekatan analisis khusus. Syamsul Ma'arif menyatakan

${ }^{6}$ Muhibbin, Psikologi Pendidikan (Bandung: PT. Rosda Karya, 2010), hal. 251

4 Jurnal Madania: Volume 9: 1, 2019 (e-ISSN 2620-8210|p-ISSN 2088-3226) 
bahwa content analysis (kajian isi) adalah teknik apapun yang digunakan untuk menarik kesimpulan melalui usaha menemukan karakteristik pesan, dan dilakukan secara objektif dan sistematis. Content analysis dapat juga digunakan untuk menganalisis semua bentuk komunikasi, baik surat kabar, berita radio,iklan televisi maupun semua bahan-bahan dokumentasi. ${ }^{7}$

2. Sumber data

Sumber data penelitian adalah bahan-bahan tulisan dan non-tulisan. Dalam hal ini, sumbur data tertulis cukup signifikan dijadikan rujukan dalam penelitian ini, terutama untuk pembahasan tentang metode pembiasaan membaca alQur'an. Dalam penelitian kepustakaan dan penerapan, sumber data yang merupakan bahan tertulis terdiri atas sumber data primer dan sumber data sekunder sebagai berikut Sumber data sekunder adapun sumber data sekunder adalah data yang sekunder adalah buku-buku yang mendukung penulis. Dalam hal ini, sumber data sekunder berupa tulisan-tulisan yang sudah mencoba membahas mengenai literatur-literatur yang relevan dengan penilitian ini. ${ }^{8}$

3. Teknik pengumpulan data

Teknik pengumpulan data merupakan langkah yang paling utama dalam penelitian, karena tujuan utama dari penelitian adalah mendapatkan data. Tanpa mengetahui teknik pengumpulan data, maka peneliti akan tidk mendapatkan data yang memenuhi standar data yang ditetapkan. ${ }^{9}$ Penelitian kepustakaan adalah cara pengumpulan data yang bersumber dari bahan- bahan bacaan seperti buku, dokumen- dokumen, arsip-arsip, dari internet (jurnal) serta literatur lainnya yang memiliki relevansi dengan permasalahan makalah ini. Cara yang ditempuh dalam penelitian ini adalah:

${ }^{7}$ Mahmud,metode penelitian pendidik an,(Bandung: pustaka setia, 2011), hlm. 31

${ }^{8}$ Saifuddin Azwar, Metode Penelitian,(Yogyakarta: PustakaPelajar, 2009), hlm. 91

${ }^{9}$ Sugiyono, Metode Penelitian Kuantitatif, Kualitatif, dan $R \& D$, (Bandung: Alfabeta, 2007),hlm. 308 
a. Kutipan, yakni cara pengumpulan data, hukum-hukum ataupun kaedah yang ditemukan dengan menyalin secara utuh sesuai naskah aslinya.

b. Ulasan, yakni cara pengupulan data, hukum ataupun kaedahkaedah yang ditemukan, kemudian diberikan ulasan dengan formulasi bahasa dari penulis sehingga memiliki korelasi yang baik dengan permasahan.

c. Ikhtisar, yaitu cara pengumpulan data, hukum ataupun kaedah yang ditemukan, dikumpulkan dan ditarik menjadi kesimpulan dengan menggunakan formulasi bahasa dari penulis tanpa merubah maksud serta isinya.

\section{Hasil dan Pembahasan}

1. Pembelajaran

a. Pengertian Pembelajaran

Pembelajaran barasal dari kata "belajar" artinya proses belajar, karena belajar merupakan kegiatan inti, sedangkan "pembelajaran mengkondisikan dan merangsang seseoang agar bisa belajar dengan baik sesuai dengan tujuan pembelajaran. ${ }^{10}$ Dengan demikian pembelajaran merupakan keseluruhan kegiatan yang memungkinkan terjadinya interaksi belaja mengajar yang melalui proses, baik yang terjadi di dalam kelas maupun di luar kelas.

Menurut Gagren yang dikutip oleh Wina sanjaya "mengajar merupakan bagian dari pembelajaran, dimana pada guru lebih ditekankan kepada bagaimana merancang sebagai sumber dan fasilitas yang tersedia untuk mengunakan atau dimanfaatkan siswa dalam memepelajari sesuatu". ${ }^{11}$ Mengajar dalam kontek standar proses pendidikan tidak hanya sekedar menyapaikan materi pelajaran, akan tetapi dimaknai sebagai proses mengatur lingkungan supaya belajar dengan baik, pembelajaran perlu memperdayakan semua potensi peserta didik menguasai kompetensi yang diharapkan.

${ }^{10}$ Ahmad Jayadi \& Abdul Majid, Tadzikirah Pembelajaran endidikan Agama Islam (PT. Raja Grajindo Persada, 2005), hal. 26.

${ }^{11}$ Wina Sanjaya , Strategi Pembelajaran Berorentasi Standar Proses Pendidikan (Jakarta: Kencana, 2008), hal. 103.

6 Jurnal Madania: Volume 9 : 1, 2019 (e-ISSN 2620-8210| p-ISSN 2088-3226) 
Pembelajaran adalah proses interaksi peserta didik dengan sumber belajar pada suatu lingkungan belajar. Pembelajaran merupakan bantuan yang diberikan pendidik agar dapat terjadi proses pemerolehan ilmu pengetahuan, dengan kata lain penbelajaran adalah proses untuk membantu peserta didik agar dapat belajar dengan baik. Proses pembelajaran disuatu pendidikan diselenggarakan secara interaktif, inspiratif, menyenangkan, memotivasi, peserta didik, untuk berpartisipasi aktif, serta memberikan ruang yang cukup bagi prakarsa, kereativitas, dan kemandirian sesuai dengan bakat, minat dan perkembangan fisik serta psikologis peserta didik. ${ }^{12}$

Proses pembelajaran adalah suatu sistem artinya suatu keseluruhan yang terjadi dari beberapa komponen-komponen yang berinteraksi antara yang satu dengan yang lain. Dengan keterkaitan antara satu dengan yang lain sehingga dapat mewujudkan tujuan pembelajaran yang baik.

b. Komponen-Komponen Pembelajaran

1). Tujuan Pembelajaran

Menurut Roestyah NK yang dikutip Syaiful Bahri Djamarah, menyatakan bahwa suatu tujuan pengajaran adalah deskripsi penampilan perilaku (performance) murid-murid yang diharapkan setelah mempelajari bahan pembelajaran memiliki perilaku yang baik. ${ }^{13}$

Tujuan pembelajaran harus dirumuskan secara spesifik dalam bentuk perilaku akhir belajar. Tujuan dalam pemelajaran adalah sebagai suatu cita-cita yang bernilai formatif yakni dalam tujuan terdapat sejumlah nilai yang harus ditanamkan pada peserta didik. Tujuan pembelajaran merupakan selalu proses yang dilakukan oleh seperangkat pendidik yang kemudian diterapkan pada peserta didik dari yang dimulai dari tahap kognisi pengertahuan dan pemahaman peserta terhadap ajaran dan nilainilai yang terkandung dalam ajaran Islam. Selanjutnya ketahap afeksi yakni terjadi proses interanalisasi ajaran dan nilai agama ke

${ }^{12}$ Peraturan Pemerintah RI No 19 Tahun 2009, Tentang Standar Nasional Pendidikan (Jakarta: Bp. Cipta Jaya, 2005), hal. 13.

${ }^{13}$ Syaiful Bahri Djamarah \& Aswan Zain, Strategi Belajar Mengajar (Jakarta: PT. Rineka Cipta, 1996), hal. 46 
dalam diri peserta didik dalam arti menghayati dan menyakininya. Melalui tahapan afeksi tersebut untuk mengamalkan dan mentaati ajaran Islam yang bisa disebut tahapan psikomotorik yang diinternalisasikan dalam diri. Dengan demikian akan terbentuk manusia muslim yang beriman dan berakhlak muliah.

2) Materi Pembelajaran

Materi pembelajaran adalah bahan yang digunakan untuk belajar yang dapat membantu untuk mencapai tujuan pembelajaran. ${ }^{14}$ Secara garis besar dapat dikemukakan bahwa materi pembelajaran adalah pengetahuan, keterampilan dan sikap yang harus dikuasai peserta didik dalam rangka memenuhi standar kompetensi yang ditetapkan. Materi pembelajaran menempati posisi yang sangat penting dari keseluruhan kurikulum, yang harus dipersiapkan agar pelaksanaan pembelajaan dapat mencapai sasaran. Sasaran tersebut harus sesuai dengan standar kompetensi dasar yang harus dicapai oleh peserta didik. Materi yang ditentukan untuk kegiatan pembelajaran hendaknya materi yang ditentukan untuk kegiatan pembelajaran yang benar-benar menunjang tercapainya standar kometensi, dan komprtensi dasar serta percapai indikator.

3) Faktor yang Mempegaruhi Kualitas Penbelajaran

Faktor yang mempengaruhi kualitas pembelajaran yaitu pelaksanaan pembelajaran kompetensi yang dimiliki oleh pendidik sangat dominan dalam mempengaruhi pembelajaran. Kompetensi yang dimaksud adalah kemampuan dasar yang dimiliki pendidik baik dibidang kognitif seperti penguasaan atas bahan ajar, bidang afektif seperti mencintai profesi serta bidang hasil kegiatan belajar.

Faktor yang mempengaruhi pembelajaran di atas, faktor yang ikut mempengaruhi yaitu kurikulum dapat mencakup lingkup yang luas dan sempit, namun dalam kedua lingkup tersebut kurikulum membentuk desain yang menggambarkan pola organisasi dari komponen-komponen kurilulum dengan pelengkapan penunjang sebagai berikut: ${ }^{15}$

${ }^{14}$ W.S Winkel, Psikologi Pengajaran ( Jakarta Grasindo, 1996), hal. 295.

15 Nanang Syaodih Sukmadinata, Pengembagan kurikulum teori dan pelaksnaan (Bandung: Remaja Reedakarya, 2002), hal. 102-105.

8 Jurnal Madania: Volume 9 : 1, 2019 (e-ISSN 2620-8210 | p-ISSN 2088-3226) 
a) Tujuan

b) Isi atau materi

c) Metode

d) Media mengajar

e) Evaluasi pengarah.

4) Tinjauan Pendidikan Agama Islam

Tujuan pendidikan agama Islam identik dengan tujuan hidup setiap manusia mendekatkan diri kepada Allah SWT. sebagaimana terdapat dalam surat Adz-Dzariyat 56 yang Artinya: "dan aku tidak menciptakan jin dan manusia melainkan supaya mereka mengabdi kepada-Ku."16

Ayat ini sesungguhnya Allah SWT. telah menciptakan manusia agar mereka mengabdi kepada-Nya dengan tidak menyekutukan-Nya dengan yang lain. Bila mereka telah menserikatkan peribadatan yang selain Aku, maka kemurkaan-Ku akan segerah menimpa mereka. Akan tetapi, bila mereka mentauhidkan Aku di dalam beribadatan, maka Aku akan meridhai mereka dan akan memasukkan mereka kedalam surge-Ku. Dan tidak diragukan lagi bahwa ini semua adalah rahmat dari padanya terhadap semua hamba-Nya. ${ }^{17}$

2. Metode Pembelajaran Dalam Pembinaan Aqidah Akhlak

a. Pengetian Metode

Metode adalah cara yang paling tepat dan cepat dalam melaksanakan sesuatu. ${ }^{18}$ Dalam peoses pendidikan, metode adalah suatu cara yang harus dilalui untuk menyajikan bahan pengajaran dan sebagai alat dalam pendidikan agar tercapai tujuan yang telah ditentukan. Hadi Susanto mengemukakan pendapat yang dikutip oleh Ramayulis yaitu metode mengajar adalah suatu "seni" dalam hal ini "seni mengajar". ${ }^{19}$ metode diartikan sebagai prinsip-prinsip atau seni yang mendasari

${ }^{16}$ Depertemen Agama RI, al-Qur'an dan Terjemahnya, (Surakarta: Media Insani Publising, 2007) hal: 523

${ }^{17}$ Muhammad Nasib Ar-Rifai, Kemudahan darib Allah Ringkasan Tafsir Ibnu Katsir Jilid 4 ( Jakarta: Gema Insani, 2006), hal. 480.

${ }^{18}$ Ahmad Tafsir, Metodologi Pengajaran Agama Islam (Banding: PT. Remaja Rosdakarya, 2003), hal. 9.

${ }^{19}$ Ramayulis, Metodologi Pengajaran Agama Islam (Jakarta: Kalam Mulia, Cet. III, 2001), hal. 
kegiatan mengarahkan perkembangan seseorang khususnya proses belajar mengajar.

Syarat-syarat yang harus tiperhatikan dalam memilih metode pembelajaran adalah sebagai berikut:

1) Metode yang dipergunakan harus dapat membangkitkan motivasi, minat atau gairah pserta didik

2) Metode yang digunakan dapat merangsang keinginan untuk belajar lebih lanjut, seperti melakukan inovasi dan eksporasi.

3) Metode yang digunakan harus dapat memberikan kesempatan bagi peserta didik untuk mewujudkan hasil karya.

4) Metode yang digunakan harus dapat menjamin perkembangan kegiatan kepribadian peserta.

5) Metode yang digunakan harus dapat mendidik dalam teknik belajar sendiri dan cara memperooleh pengetahuan melalui usaha sendiri.

6) Metode yang digunakan harus dapat menanamkan dan mengembangkan nilai-nilai dan sikap peserta didik dalam kehidupan sehari-hari. ${ }^{20}$

b. Pengunaan Metode Pembelajaran

Metode belajar merupakan salah satu cara yang dipergunakan dalam proses belajar pada saat berlangsungnya pembelajaran. Oleh karena itu peranan metode belajar sebagai alat untuk menciptakan proses belajar mengajar. Dengan metode belajar diharapkan tumbuh berbagai kegiatan belajar, sehubungan dengan kegiatan mengajar. Dengan kata lain, tercipta interaksi edukatif, dalam interaksi ini, mengajar berperan sebagai pengerak atau Pembina, sedangkan peserta didik berperan sebagai penerima atau dibina dan dibimbing. Pengajar diharapkan mampu memilih dan menggunakan metode pembelajaran sesuai dengan materi yang disampaikan.

Menurut Nana Sudjana yang dikutip oleh Suryosubroto, mengemukakan dalam peraktek mengajar, motode yang baik digunakan adalah metode mengajar yang bervariasi atau kombinasi dan beberapa metode mengajar. ${ }^{21}$ Memvariasikan penggunaan metode pembelajaran dalam mengajar dimaksudkan

${ }^{20}$ Ahmad Sabri, Strategi Belajar Mengajar (Ciputat: Pres, Cet.II, 2007), hal.50.

${ }^{21}$ Suryosubroto, Proses Belajar Mengajar (Jakata: PT. Rineka Cipta), hal. 49.

10 Jurnal Madania: Volume 9 : 1, 2019 (e-ISSN 2620-8210|p-ISSN 2088-3226) 
untuk menjambatani peserta didik dan menghindari terjadi kejenuhan yang dialami oleh pelajar.

Pada pembelajaran aqidah akhlak untuk meningkatkan keberhasilan dalam pembinaan aqidah akhlak pada pelajar penerapan pembelajaran dapat digunakan berbagai pendekatan dengan memilih pendekatan yang terbaik dan saling mengaitkan satu sama lain agar dapat menimbulkan hasil yang obtimal. Pendekatan-Pendekatan yang dimaksud antara lain sebagai:

1) Pendekatan Penanaman Nilai (Inculcation Approach)

Pendekatan ini mengusahakan agar peserta didik menerima nilai sebagai milik dan bertanggung jawab atas keputusan yang diambil melalui tahapan: mengenal pilihan, menilai pilihan, menentukan pendirian, dan menerapkan nilai sesuai dengan keyakinan diri. Cara yang digunakan pada pendekatan ini antara lain: keteladanan, penguatan positif dan negative, simulasi dan permainan peran.

2) Pendekatan Perkembangan Moral Kognitif (Cognitive Moral Developmeni Approach)

Pendekatan ini menekankan pada berbagai tingkatan dari pemikiran moral. Pembina dapat mengarahkan peserta didik dalam menerapkan proses pemikiran melalui diskusi masalah moral sehingga peserta didik dapat membuat keputusan tetang pendapat moral mereka akan menggambarkan tingkat yang lebih tinggi dalam pemikiran moral yaitu takut hukuman, melayani kehendak sendiri, menuruti peranan yang diharapkan, menuruti dan menaati otoritas, berbuat untuk kebaikan yang banyak, dan bertindak sesuai dengan perinsip-perinsip etika yang universal. Cara yang digunakan dalam penerapan pembelajaran dengan pendekatan ini antara lain: melakukan diskusi kelompok dengan topik dilema moral, baik yang faktual maupun yang abstrak.

3) Pendekatan Analisis Nilai (Value Analysis Approach)

Pendekatan ini menekankan agar peserta didik dapat menggunakan kemampuan berfikir logis dan ilmiah dalam menganalisis masalah sosial yang berhubungan dengan nilai tertentu, selain itu peserta didik dalam menggunakan proses berfikir rasional dan analisis dapat digunakan dalam pendekatan ini antara lain: diskusi yang menuntut argumentasi, penegasan 
buku, penegasan perinsip, analisis terhadap kasus, debat, dan penelitian.

4) Pendekatan Klasifikasi Nilai (ValuaesClarification Appoarch) Pendidikan ini bertujuan untuk menumbuhkan kesadaran dan pengembangan kemampuan peserta didik untuk mengidentifikasi nilai-nilai mereka sendiri dan nilai-nilai orang lain, selain itu, pendekatan ini juga membantu peserta didik untuk mampu mengkomonikasikan secara jujur dan terbuka tetang nilainilai mereka sendiri kepada orang lain akan membantu peserta didik dalam menggunakan kemampuan berpikir rasional dan emosional dalam menilai perasaan dan tingkah laku mereka sendiri, aktivitas yang mengembangkan sensitivitas, kegiatan diluar kelas dan diskusi kelompok.

6) Pendekatan pembelajaran Berbuat (Action Learning Approach)

Pendekatan ini bertujuan untuk mengembangkan kemampuan peserta didik, seperti pada pendekatan analisis dan klaifikasi nilai. Selain itu, pendekatan ini untuk mengembangkan kemampuan peserta didik dalam melakukan kegiatan sosial serta mendorong pelajar untuk melihat diri sendiri sebagai makhluk yang senantiasa berinteraksi dalam kehidupan bermasyarakat. Cara yang dapat digunakan dalam pendekatan dengan metode proyek, hubungan antara pribadi, praktik hidup bermasyarakat, dan berorganisasi. ${ }^{22}$

c. Pengertian Pembinaan Aqidah Akhlak

1) Pengertian Pembinaan

Pembinaan adalah proses, cara, perbuatan pembaharuan, penyempurnaan, usaha, tindakan, dan kegiatan yang dilakukan secara efektif dan efesien untuk memperoleh hasil yang lebih baik. ${ }^{23}$ Pembinaan juga dikatakan kegiatan mempertahankan dan menyempurnakan apa yang telah ada dan dilakukan secara berulang-ulang. Pembinaan dapat diartikan sebagai upaya memelihara dan membawa suatu keadaan yang seharusnya terjadi atau menjaga keadaan sebagaimana seharusnya.

${ }^{22}$ Nurul Zuriah, Pendidikan Meorak \& Budi Pekerti dalam Prespektif Perubahan: Meggagas Platform Pendidikan Budi Pekerti Secara Kontekstual dan Foturistik (Jakarta: PT Bumi Aksara), hal. 220-221

${ }^{23}$ Depertemen Pendidikan Nasional, Kamus Besar Indonesia Pusat Bahasa (Jakarta: Gramedia Pustaka Utama, 2008), hal. 193.

12 Jurnal Madania: Volume 9: 1, 2019 (e-ISSN 2620-8210| p-ISSN 2088-3226) 
Jadi yang dimaksud dengan membina adalah merupakan usaha, kegiatan mengarahkan dalam melaksanakan suatu kegiatan pendidikan yang baik secara teori mupun praktek agar kegiatan berjalan sesuai dengan tujuan yang diinginkan.

2) Pengeriaan Aqidah Akhlak

Kata Aqidah menurut bahasa berasal dari kata al-Aqdu yang berarti ikatan, At-Tautsiqu yang berari keparcayaan atau keyakinan kuat. Al-lhkamu artinya mengokohkan atau menetapkan dan ar-rabthu biquwwah yang berarti mengikat yang kuat. Sedangkan menurut istilah adalah iman yang teguh dan pasti, yang tidak ada keraguan sedikitpun bagi orang yang meyakini. ${ }^{24}$ Jadi aqidak adalah yang dipercayai dan diyakini kebenarannya dengan hati manusia, sesuai ajaran Islam dengan berpedoman kepada al-Qur'an dan Hadits, oleh karena itu ia terpelihara kemurniannya dengan baik.

Kata Akhlak menurut bahasa arab yang merupakan jamak dari kata khuluq yang berarti adat kebiasaan, perangai, tabiat. ${ }^{25}$ Sedangkan secara teminologi, menurut Imam Al-Gazali yang dikutip Samsul Munir Amin "Akhlak adalah sifat yang tertanan dalam jiwa yang dari padanya lahir perbuatan-perbuatan yang spontan tanpa memerlukan pertimbangan dan pemikiran". Maka jika sifat tersebut melahirkan sesuatu tindakan yang terpuji menurut ketentuan akal dan norma agama, ia dinamakan akhlak yang baik, tetapi jika ia menimbulkan tindakan yang jahat, maka dinamakan akhlak yang buruk. ${ }^{26}$

Kesempurnaan akhlak seseorang harus melatih diri dan membiasakan dalam hidup sehari-hari. Seseorang harus selalu berlatih dan membiasakan diri berfikir dan berkehendak baik, serta membiasakan mewujudkan pemikiran dan kehendak baik, dalam hidup sehari-hari. Karena akhlak seseorang bukanlah tindakan yang direncanakan pada saat tertentu saja, namun akhlak merupakan keutuhan kehendak dan perbuatan yang melekat pada seseorang yang akan tampak pada perilaku sehari-

${ }^{24}$ Yazid Bin Abdul Qarir Jawas, Syarah Aqidah Ahlus Sunnah Wal Jama'ah (Bandung: Pustaka At-Taqwa, 2004), hal. 35.

25 Samsul Munir Amin, Ilmu Akhlak (Jakarta: Bumi Akrasa, 2016), hal. 1.

26 Ibid, hal. 3. 
hari.

a. Metode Pembinaan Aqidah Akhlak

1) Metode ceramah

Metode ceramah diartikan sebagai proses penyampaian informasi dengan jalan menuturkan materi secara lisan, atau penjelasan secara langung kepada sekelompok peserta didik cara bicara dan sistimatika pembicaraan, jumlah materi yang disajikan, kemampuan member ilusterasi, jumlah peserta didik yang mendengar dan lain-lain. ${ }^{27}$

2) Metode Pembiasaan/latihan

Metode pembiasaan merupakan cara menyampaikan pendidikan dengan membiasakan perbuatan perbuatanperbuatan yang baik sesuai dengan tingkat kemampuan. Karena berbuatan tersebut akan membiasakan/latihan yaitu membiasakan jangan sampai membosankan, karena waktu yang digunakan cukup singkat. Latihan betul-betul diatur dengan sedemikian rupa, sehingga latihan itu manarik peserta didik. Agar peserta didik tidak ragu maka terlebih dahulu diberikan pengertian dasar tentang materi yang akan diberikan. ${ }^{28}$

3) Metode Pemberian contoh dan telandan

Metode ini yang cukup besar pengaruhnya dalam mendidik, Allah telah menunjukkan contoh keteladanan dari kehidupan Nabi Muhammad SAW. sebagaimana Firman Allah dalam al-Qur'an surat al-Ahzab ayat:21:

Atrinya

"Sesungguhnya telah ada pada (diri) Rasulullah itu suri teladan yang baik bagimu (yaitu) bagi orang yang mengharap (rahmat) Allah dan (kedatangan) hari kiamat dan Dia banyak menyebut Allah." ${ }^{29}$

4) Metode pemberian Hadiah dan Hukuman

Metode hadiah adalah sesuatu yang mengembirakan dapat

${ }^{27}$ Depertemen Agama RI, al-Qur'an dan Terjemahnya, (Jakarta: Media Insani Publising, 2007) hal: 420

${ }^{28}$ Zekiah Derajat, Metode Khussus Pengajaran Agama Islam (Jakarta: Bumi Aksara, 2004), hal. 304

${ }^{29}$ Depertemen Agama RI, AL-Qur'an dan Terjemahan (Surakarta: Media Insani Publising, 2007), hal. 420

14 Jurnal Madania: Volume 9: 1, 2019 (e-ISSN 2620-8210| p-ISSN 2088-3226) 
merangsang psikologi untuk lebih berprestasi, sedangakan hukuman menyedihkan yang juga adapat berpengaruh pada rohani dan jasmani anak. Konsep hadiah dan hukuman ini dipandang dari sudut Islam adalah konsep yang sudah jelas tentera secara eksprisit dan qath'i dalam al-Qur'an dan Hadits. ${ }^{30}$

5) Metode Bercerita

Metode ini ada.lah dengan mengisahkahkan peristiwa sejarah hidup manusia masa lampau yang menyangkut ketaatannya atau kemungkaran dalam hidup terhadap perintanh Allah SWT. yang dibawakkan oleh Nabi atau Rasul. ${ }^{31}$ Cerita termasuk salah satu media pembelajaran yang sukses. la merupakan satu cara pendidikan yang disenangi pserta didik dan pendidik. ${ }^{32}$

6) Metode Pemecahan masalah

Metode ini adalah suatu cara menyajikan pelajaran dengan mendorong peserta didik untuk mencari dan memecahkan suatu persoalan dalam rangkah mencapai tujuan pelajaran. ${ }^{33}$

7) Metode Penkunjungan Studi

Metode ini adalah suatu cara menyajikan pelajaran dengan mengadakan perkunjungan kesuatu objek di luar kelas dengan maksud untuk mencapai tujuan. ${ }^{34}$

\section{Kesimpulan}

Pembelajaran adalah proses interaksi peserta didik dengan sumber belajar pada suatu lingkungan belajar. Pembelajaran merupakan bantuan yang diberikan pendidik agar dapat terjadi proses pemerolehan ilmu pengetahuan, untuk membantu peserta didik agar dapat belajar dengan baik untuk meningkatkan keberhasilan dalam pembinaan aqidah akhlak dapat digunakan berbagai pendekatan dengan memilih pendekatan yang terbaik dan saling mengaitkan satu sama lain agar dapat menimbulkan hasil yang obtimal. Motode

${ }^{30}$ Haidar Putra Daulay, Pendidikan Islam dalam Perspektif Filsafat (Jakarta: Pranemedia Group, 2014), hal. 120.

${ }^{31}$ Hasan Basri, Ilmu Pendidikan Agama Islam (Bandung: Pustaka Setia, 2010), hal. 171.

${ }^{32}$ Haidar Putra Daulay, Pendidikan Islam ...hal. 132.

${ }^{33}$ Ramayulis, Metodologi Pengajaran Agama Islam... hal. 207 34 Ibid, hal. 190. 
pembelajarn yang baik digunakan dalam bembinana aqidah akhlak adalah metode mengajar yang bervariasi atau kombinasi dan Memvariasikan penggunaan metode pembelajaran untuk menjambatani peserta didik dan menghindari terjadi kejenuhan pada pembelajaran aqidah akhlak.

\section{Daftar Pustaka}

Akmal Wahi, Kompetensi Guru Pendidikan agama Islam (Jakarta: ajawali Press, 2014

Agung Suprijono, Comeraive Learning tweri dan Alikas aikem

Yogjakarta: ustaka Pelajar, 2011

Ahmad Jayadi \& Abdul Majid, Tadzikirah Pembelajaran endidikan Agama Islam (PT. Raja Grajindo Persada, 2005

Ahmad Sabri, Strategi Belajar Mengajar Ciputat: Pres, Cet.II, 2007 Ahmad Tafsir, Metodologi Pengajaran Agama Islam (Banding: PT. Remaja Rosdakarya, 2003

Depertemen Pendidikan Nasional, Kamus Besar Indonesia Pusat

Bahasa Jakarta: Gramedia Pustaka Utama, 2008

Enang Hidayat, Pendidikan Agama IslamIntegrasi Nilai-Nilai Aqidah Alkhkan Bandung: PT. Ramaja Rodaksrys 2018

Haidar Putra Daulay, Pendidikan Islam dalam Perspektif Filsafat Jakarta: Pranemedia Group, 2014

Hasan Basri, IImu Pendidikan Agama Islam Bandung: Pustaka Setia, 2010

Haidar Putra Daulay, Pendidikan Islam dalam Perspektif Filsafat Jakarta: Pranemedia Group, 2014

Muhibbin, Psikologi Pendidikan (Bandung: PT. Rosda Karya, 2010 Mahmud, Metode penelitian pendidik an,(Bandung: pustaka setia, 2011

Muhammad Nasib Ar-Rifai, Kemudahan darib Allah Ringkasan Tafsir Ibnu Katsir Jilid 4 Jakarta: Gema Insani, 2006

Nanang Syaodih Sukmadinata, Pengembagan kurikulum teori dan pelaksnaan Bandung: Remaja Reedakarya, 2002 Peraturan Pemerintah RI No 19 Tahun 2009, Tentang Standar Nasional Pendidikan Jakarta: Bp. Cipta Jaya, 2005 
Ramayulis, Metodologi Pengajaran Agama Islam (Jakarta: Kalam Mulia, Cet. III, 2001

Samsul Munir Amin, Ilmu Akhlak Jakarta: Bumi Akrasa, 2016 Sulistyorini, Manajemen Pendidikan Islam, aplikasi, Strategi, dan Aplikasih Yogyakarta : Teras 2009

Saifuddin Azwar, Metode Penelitian,(Yogyakarta: PustakaPelajar, 2009

Sugiyono, Metode Penelitian Kuantitatif, Kualitatif, dan $R \& D$, (Bandung: Alfabeta, 2007

Syaiful Bahri Djamarah \& Aswan Zain, Strategi Belajar Mengajar Jakarta: PT. Rineka Cipta, 1996

W.S Winkel, Psikologi Pengajaran Jakarta Grasindo, 1996

Wina Sanjaya, Stategi embelajaran Berorintasi Standar Pendidikan Jakarta: Kencana renada Media Group, 2014

Wina Sanjaya, Strategi Pembelajaran Berorentasi Standar Proses Pendidikan (Jakarta: Kencana, 2008

Yazid Bin Abdul Qarir Jawas, Syarah Aqidah Ahlus Sunnah Wal Jama'ah Bandung: Pustaka At-Taqwa, 2004

Zekiah Derajat, Metode Khussus Pengajaran Agama Islam Jakarta: Bumi Aksara, 2004 